J. Clin. Chem. Clin. Biochem.

Vol. 26, 1988, pp. 673-678

(C) 1988 Walter de Gruyter \& Co.

Berlin - New York

\title{
Phenothiazines Inhibit Cholesteryl Ester Formation in J 774 Monocyte-Like Cells
}

\author{
By N. E. Houtia, J. C. Mazière, C. Mazière, M. Auclair
}

Laboratoire de Biochimie, CNRS UA 524, Faculté de Médecine Saint-Antoine

J. Gardette

* INSERM U 181, Faculté de Médecine Saint-Antoine, Paris, France and

\section{J. Polonovski}

Laboratoire de Biochimie, CNRS UA 524, Faculté de Médecine Saint-Antoine, Paris, France

(Received March 22/June 23, 1988)

Summary: The effect of phenothiazines (trifluoperazine and chlorpromazine) on cholesteryl ester metabolism has been investigated in $\mathrm{J} 774$ mouse monocyte-macrophages. The incorporation of oleic acid into cholesteryl ester and the activity of acylcoenzyme A : cholesterol-O-acyltransferase were strongly decreased in cells pretreated for $24 \mathrm{~h}$ with trifluoperazine or chlorpromazine. Furthermore, trifluoperazine or chlorpromazine decreased the degradation of acetylated low density lipoprotein by $\mathrm{J} 774$ cells. When cell homogenates were preincubated in vitro with trifluoperazine or chlorpromazine, a marked inhibition of acylcoenzyme A : cholesterol-O-acyltransferase activity was observed. In cells incubated with acetylated low density lipoprotein loaded with radiolabeled cholesteryl-linoleate, trifluoperazine and chlorpromazine dramatically reduced the radioactivity recovered in cholesteryl esters. The radioactivity recovered in free cholesterol was also decreased, but to a lesser extent. These results suggest that phenothiazines could efficiently antagonize cholesteryl ester accumulation in macrophages by at least two different mechanisms: a reduction of modified LDL catabolism, and a direct inhibition of the enzyme acylcoenzyme A : cholesterol-O-acyltransferase.

\section{Introduction}

Atherosclerotic lesions have been demonstrated to be infiltrated by foam cells derived from monocyte-macrophages overloaded with cholesterỳl esters (1). Mahley et al. (2) and Goldstein et al. (3) reported the existence of receptors for modified low-density lipoproteins (LDL), such as acetylated LDL, at the surface of macrophages, and such receptors have also been found in monocytes by Fogelman et al. (4). Uptake of modified LDL by monocyte-derived macrophages leads to massive accumulation of cholesteryl esters, due to a dramatic increase in acylcoenzyme $\mathrm{A}$ : cholesterol-O-acyltransferase activity $(2-4)$. Overloading of monocyte-derived macrophages with cho- lesteryl esters occurs because modified LDL uptake is not down-regulated (4). This process is currently believed to be closely involved in the appearance of atherosclerotic lesions (1).

We previously reported a biphasic effect of phenothiazines such as trifluoperazine and chlorpromazine on LDL and sterol metabolism in human fibroblasts (5, $6)$. We demonstrated that these drugs are potent inhibitors of cholesterol esterification in fibroblasts (6). Such an effect has been also reported for chlorpromazine in another experimental model, the arterial wall, by Bell $(7,8)$. In view of the fact that cholesteryl ester accumulation is closely involved in atherogenesis, it 
was of interest to investigate the effect of phenothiazines on cholesterol esterification in the monocytemacrophage. In the present work, we demonstrated a strong inhibition of cholesteryl ester formation by trifluoperazine and chlorpromazine in $\mathrm{J} 774$ mouse monocyte-like cells.

\section{Materials and Methods}

\section{Materials}

Trifluoperazine and chlorpromazine were from Sigma Chemical Co., St. Louis, MO, U.S. A. $\left[1-^{14} \mathrm{C}\right]$ oleic acid $2.11 \mathrm{GBq} / \mathrm{mmol}$, $\left[1-{ }^{14} \mathrm{C}\right]$ oleoyl Coenzyme A $2.11 \mathrm{GBq} / \mathrm{mmol}$ and ${ }^{125} \mathrm{INa} 481 \mathrm{GBq} /$ mg were from Amersham, Buckinghamshire, U.K. [cholesteryl$\left.1,2,6,7-{ }^{3} \mathrm{H}(\mathrm{N})\right]$ cholesteryl linoleate $3704 \mathrm{GBq} / \mathrm{mmol}$ was from New England Nuclear, Boston, U.S. A. Dulbecco modified Minimum Essential Medium with Earle's salts and foetal calf serum were from Gibco, Grand Island, NY, U.S. A.; Ultroser $G$ from Industries Biologiques Françaises, Villeneuve la Garenne, France; J 774 mouse macrophages from the American Type Culture Collection, Camden, New Jersey, U.S. A. Silica gel plates F 1500 were from Schleicher and Schuell, Dassel, W.-Germany.

\section{Cell culture}

$\mathrm{J} 774$ cells were cultured in $35 \mathrm{~mm}$ Nunc Petri dishes containing $1 \mathrm{ml}$ Dulbecco MEM medium supplemented with $20 \mathrm{mmol}$ Hepes buffer ( $\mathrm{pH} 7.4$ ), penicillin, streptomycin, and foetal calf serum, volume fraction 0.1 , at $37^{\circ} \mathrm{C}$ in a humidified atmosphere of $5 \% \mathrm{CO}_{2} 95 \%$ air. For experiments, foetal calf serum was replaced by $2 \%$ Ultroser $G$ and $50 \mathrm{mg} / \mathrm{l}$ acetylated-LDL for induction of acylcoenzyme $A$ : cholesterol-O-acyltransferase.

\section{LDL preparation and acetylation}

LDL was prepared from normal human serum by 3 step ultracentrifugation at $105000 \mathrm{~g}$ in a L5-50 Beckman instrument, according to Havel et al. (9). The LDL was taken as the 1.0241.050 fraction. Acetylation was performed by the method of Basu et al. (10).

\section{Labeling of acetylated LDL with ${ }^{125} \mathrm{INa}$}

Acetylated-LDL was labeled with ${ }^{125} \mathrm{INa}$ according to Bilheimer et al. (11). The specific radioactivity was about $3.7 \mathrm{KBq} / \mathrm{mg}$ of acetylated LDL protein. Protein was determined by the method of Lowry et al. (12).

\section{Acetylated LDL catabolism}

Cells were incubated for $24 \mathrm{~h}$ in medium devoid of lipoproteins (supplemented with $2 \%$ Ultroser $G$ ) in the absence or in the presence of drugs. After 3 washes with a phosphate-buffered solution pH 7.4, the catabolism of modified LDL was studied according to Goldstein et al. (13), with $10 \mathrm{mg} / 1^{125}$ I-acetylatedLDL. Results are expressed in $\mathrm{ng}{ }^{125}$ I-acetylated LDL per $\mathrm{mg}$ of cellular protein.

Labeling of acetylated LDL with cholesteryl linoleate

$\left[{ }^{3} \mathrm{H}\right]$ cholesteryl linoleate was incorporated into acetylated LDL by the technique of Friedman et al. (14), using dimethylsulphoxide. The specific radioactivity was about $2 \mathrm{MBq} / \mathrm{mg}$ of $\mathrm{LDL}$ protein.
Oleic acid incorporation into cholesteryl ester and triacylglycerols

Cells were incubated for $24 \mathrm{~h}$ in Dulbecco's MEM medium supplemented with $2 \%$ Ultroser $\mathrm{G}$ and $50 \mathrm{mg} / \mathrm{l}$ acetylated LDL for induction of the acylcoenzyme A : cholesterol-O-acyltransferase activity, in the presence or in the absence of trifluoperazine or chlorpromazine at the concentrations indicated. [1${ }^{14} \mathrm{C}$ ]oleic acid $37 \mathrm{MBq} / \mathrm{l}$ was then added and incubation further performed $4 \mathrm{~h}$ at $37^{\circ} \mathrm{C}$. Cells were washed 4 times with a phosphate-buffered solution $\mathrm{pH} 7.4$, harvested with ribber policemen, and centrifuged; lipid analysis was performed by thin layer chromatography (15). Results were expressed as pmol of precursor incorporated per $\mathrm{mg}$ of cell protein.

Acylcoenzyme A : cholesterol-O-acyltransferase activity

Acylcoenzyme A : cholesterol-O-acyltransferase activity was measured according to Brown et al. (16), in two different systems:

1. sonicated homogenates of cells preincubated for $24 \mathrm{~h}$ in medium containing $2 \%$ Ultroser G + acetylated LDL $50 \mathrm{mg} / 1$ in the absence or in the presence of drugs, or

2. homogenates of untreated cells preincubated 30 minutes at $37^{\circ} \mathrm{C}$ with gentle shaking with trifluoperazine or chlorpromazine just before the measurement of acylcoenzyme $A$ : cholesterol-O-acyltransferase activity. Each assay contained $100 \mu \mathrm{g}$ of protein, sodium phosphate buffer $0.1 \mathrm{~mol} / 1 \mathrm{pH} 7.4, \mathrm{MgCl}_{2}$ $5 \mathrm{mmol} / \mathrm{l}$, bovine serum albumin $0.2 \mathrm{~g} / \mathrm{l},\left[1-{ }^{14} \mathrm{C}\right]$ oleoyl coenzyme $\mathrm{A}(3.7 \mathrm{KBq})$ and unlabeled oleoyl-coenzyme $\mathrm{A}$ (final concentration $10 \mu \mathrm{mol} / \mathrm{l})$. The final incubation volume was $100 \mu \mathrm{l}$. The reaction was carried out for 5 minutes at $37^{\circ} \mathrm{C}$ and stopped on ice. An aliquot of the incubation mixture was then put on a silica gel plate, and neutral lipids were separated by thin layer chromatography as described above. Spots corresponding to cholesteryl ester were cut out and the radioactivity was counted by liquid scintillation. Acylcoenzyme A : cholesterol-O-acyltransferase activity was expressed as $\mathrm{nmol} / \mathrm{h} \cdot \mathrm{mg}$ of cell protein.

\section{Metabolism of cholesteryl linoleate-labeled LDL}

Cells were preincubated for $24 \mathrm{~h}$ in Dulbecco's MEM medium supplemented with foetal calf serum, volume fraction 0.1 , in the absence or in the presence of trifluoperazine or chlorpromazine $10 \mu \mathrm{mol} / \mathrm{l}$. Acetylated LDL labeled with $\left[{ }^{3} \mathrm{H}\right]$ cholesteryl linoleate was then added at a concentration of $10 \mathrm{mg} / \mathrm{l}$. After a further $24 \mathrm{~h}$ incubation at $37^{\circ} \mathrm{C}$, cells were washed 4 times with a phosphate-buffered solution $\mathrm{pH} 7.4$, harvested with rubber policemen, and centrifuged; lipid analysis was performed on aliquots of the cell suspension after direct application to silica gel plates as previously described (15). The solvent system was hexane/diethylether/acetic acid 70/30/2 (by vol.). After autoradiography, lipids were identified by comparison with purified standards (Sigma). Spots corresponding to cholesterol and cholesteryl esters were cut out and their radioactivity measured by liquid scintillation in an Intertechnique instrument. Results are expressed in fmol of $\left[{ }^{3} \mathrm{H}\right]$ cholesterol per $\mathrm{mg}$ of cell protein.

\section{Results}

Table 1 presents the effect of trifluoperazine and chlorpromazine on $\left[{ }^{14} \mathrm{C}\right]$ oleic acid incorporation into cholesteryl esters and triacylglycerols by $\mathrm{J} 774$ cells. A dose-dependent decrease in cholesterol esterification was observed; in the presentie of $10 \mu \mathrm{mol} / 1 \mathrm{tri}$ - 
Tab. 1. Effect of trifluoperazine and chlorpromazine on $\left[{ }^{14} \mathrm{C}\right]$ oleic acid incorporation into cholesteryl esters and triacylglycerols. Cells were preincubated for $24 \mathrm{~h}$ in Dulbecco's MEM medium supplemented with $2 \%$ Ultroser $G$ and acetylated LDL $50 \mathrm{mg} / \mathrm{l}$, in the absence or in the presence of the drugs. $\left[{ }^{14} \mathrm{C}\right]$-oleic acid was then added $(37 \mathrm{MBq} / \mathrm{l})$ and incubation further performed for $4 \mathrm{~h}$ at $37^{\circ} \mathrm{C}$ before lipid analysis. Results are expressed as pmol of oleic acid incorporated per $\mathrm{mg}$ of cell protein (means of 4 experimental values $\pm S . D$.).

\begin{tabular}{lcc}
\hline $\begin{array}{l}\text { Addition } \\
(\mu \mathrm{mol} / \mathrm{l})\end{array}$ & \multicolumn{2}{c}{ Oleic acid incorpotiation into } \\
\cline { 2 - 3 } & cholesteryl esters & triacylglycerols \\
\hline None & $2590 \pm 350$ & $1150 \pm 168$ \\
Trifluoperazine & & \\
1 & $2020 \pm 275^{*}$ & $1980 \pm 175$ \\
5 & $1320 \pm 180^{* * *}$ & $1220 \pm 155$ \\
10 & $730 \pm 115^{* * *}$ & $1375 \pm 152$ \\
Chlorpromazine & & \\
1 & $2200 \pm 280$ & $980 \pm 160$ \\
5 & $1805 \pm 234^{*}$ & $1085 \pm 142$ \\
10 & $910 \pm 145^{* * *}$ & $1280 \pm 180$ \\
\hline
\end{tabular}

*: $\mathrm{p}<0.05 ;{ }^{* * *}: \mathrm{p}<0.001$ by the Student's t-test.

Tab. 2. Effect of trifluoperazine and chlorpromazine on acylcoenzyme A : cholesterol-O-acyltransferase activity of J 774 macrophages. Cells were preincubated for $24 \mathrm{~h}$ in the absence or in the presence of drugs as specified in the legend to tab. 1. After 3 washes, cells were harvested with rubber policemen and acylcoenzyme $\mathrm{A}$ : cholesterol-O-acyltransferase activity was measured on cell homogenates over a period of 5 minutes at $37^{\circ} \mathrm{C}$. Results are expressed in $\mathrm{nmol} / \mathrm{h} \cdot \mathrm{mg}$ protein (means of 4 experimental values \pm S. D.).

\begin{tabular}{ll}
\hline $\begin{array}{l}\text { Addition } \\
(\mu \mathrm{mol} / \mathrm{l})\end{array}$ & $\begin{array}{l}\text { Acylcoenzyme A : cholesterol-O-acyl- } \\
\text { transferase activity (nmol/h-mg protein) }\end{array}$ \\
\hline None & $11.6 \pm 2.2(100 \%)$ \\
Trifluoperazine & \\
1 & $8.0 \pm 1.5(69 \%)^{*}$ \\
5 & $4.5 \pm 0.9(39 \%)^{* * *}$ \\
10 & $1.9 \pm 0.4(16 \%)^{* * *}$ \\
Chlorpromazine & \\
1 & $9.3 \pm 1.8(80 \%)$ \\
5 & $5.1 \pm 1.5(44 \%)^{* * *}$ \\
10 & $2.4 \pm 0.6(21 \%)^{* * *}$ \\
\hline
\end{tabular}

*: $\mathrm{p}<0.05 ;{ }^{* * *}: \mathrm{p}<0.001$ by the Student's t-test.

fluoperazine or chlorpromazine, the decrease was about $70 \%$ or $65 \%$, respectively. $\left[{ }^{14} \mathrm{C}\right]$ oleic acid incorporation into triacylglycerols, taken as an internal control, was not significantly affected.

Table 2 shows that a $24 \mathrm{~h}$ preincubation of $\mathrm{J} 774$ cells with trifluoperazine or chlorpromazine resulted in a marked reduction of the acylcoenzyme A : cholesterol$\mathrm{O}$-acyltransferase activity further measured in vitro. A dose-dependent inhibition was observed, with about $60 \%$ reduction at $5 \mu \mathrm{mmol} / \mathrm{l}$, and $80 \%$ decrease at $10 \mu \mathrm{mmol} / 1$, in either trifluoperazine-treated or chlorpromazine-treated cells.

From these results, it is concluded that phenothiazines either directly inhibit acylcoenzyme A : cholesterol$\mathrm{O}$-acyltransferase, or/and decrease its activity indirectly by affecting acetylated LDL metabolism, since it is known that the acylcoenzyme $\mathrm{A}$ : cholesterol-Oacyltransferase activity of macrophages is highly dependent on the uptake and degradation of modified $\operatorname{LDL}(2,3)$. In order to investigate these possibilities, we further studied the effect of phenothiazines on acetylated LDL catabolism by $\mathrm{J} 774$ cells. Table 3 shows that both trifluoperazine and chlorpromazine decreased [ $\left.{ }^{125} \mathrm{I}\right]$ acetylated LDL degradation by $\mathrm{J} 774$ cells, with about $60 \%$ and $55 \%$ reduction for trifluoperazine and chlorpromazine $(10 \mu \mathrm{mol} / \mathrm{l})$, respectively. Concomitantly, the intracellular radioactivity, corresponding to undegraded acetylated LDL, was markedly increased in both cases. The total radioactivity (intracellular + degraded) remained unchanged, indicating that the increased intracellular radioactivity merely reflected the reduced lysosomal degradation.

We also investigated the possibility of a direct inhibition of the acylcoenzyme A : cholesterol-O-acyltransferase activity by phenothiazines, in experiments performed with homogenates of untreated $\mathrm{J} 774$ cells submitted to a short in vitro preincubation at $37^{\circ} \mathrm{C}$ in the presence of the drugs. Table 4 shows that under these conditions, chlorpromazine and trifluoperazine also decreased the acylcoenzyme A : cholesterol-Oacyltransferase activity, although higher concentra-

Tab. 3. Effect of trifluoperazine and chlorpromazine on acetylated LDL catabolism by J 774 cells. Cells were preincubated for $24 \mathrm{~h}$ with drugs, then washed and further incubated $4 \mathrm{~h}$ at $37^{\circ} \mathrm{C}$ with [ $\left.{ }^{125} \mathrm{I}\right]$ acetylated LDL 10 $\mathrm{mg} / \mathrm{l}$. Results are expressed in $\mathrm{ng}\left[{ }^{125} \mathrm{I}\right]$ acetylated LDL per mg cellular protein (means of 3 experimental values \pm S. D.).

\begin{tabular}{lll}
\hline $\begin{array}{l}\text { Addition } \\
(\mu \mathrm{mol} / \mathrm{l})\end{array}$ & Intracellular & Degraded \\
\hline None & $3440 \pm 520$ & $5200 \pm 800$ \\
Trifluoperazine & & \\
1 & $4200 \pm 475^{*}$ & $3860 \pm 330^{*}$ \\
5 & $6190 \pm 470^{* *}$ & $3120 \pm 410^{* *}$ \\
10 & $7200 \pm 840^{* * *}$ & $2190 \pm 270^{* * *}$ \\
Chlorpromazine & & \\
1 & $3880 \pm 265$ & $4240 \pm 510$ \\
5 & $5400 \pm 600^{* *}$ & $3780 \pm 455^{*}$ \\
10 & $6800 \pm 810^{* * *}$ & $2430 \pm 340^{* * *}$ \\
\hline
\end{tabular}

*: $\mathrm{p}<0.05 ;{ }^{* *}: \mathrm{p}<0.01$ * $^{* * *}: \mathrm{p}<0.001$ by the Student's t-test. 
Tab. 4. Effect of short term in vitro preincubation of $\mathrm{J} 774$ cell homogenates with trifluoperazine or chlorpromazine on acylcoenzyme A : cholesterol-O-acyltransferase activity. Homogenates of $\mathrm{J} 774$ cells pretreated for $24 \mathrm{~h}$ in medium supplemented with Ultroser G $2 \%+$ acetylated LDL $50 \mathrm{mg} / 1$ were incubated 30 minutes at $37^{\circ} \mathrm{C}$ with gentle shaking in the absence or in the presence of the drugs; acylcoenzyme A : cholesterol-O-acyltransferase activity was then measured over a period of 5 minutes at $37^{\circ} \mathrm{C}$. Enzyme activity is expressed in $\mathrm{nmol} / \mathrm{h} \cdot \mathrm{mg}$ of cellular proteins (means of 3 experimental values \pm S. D.).

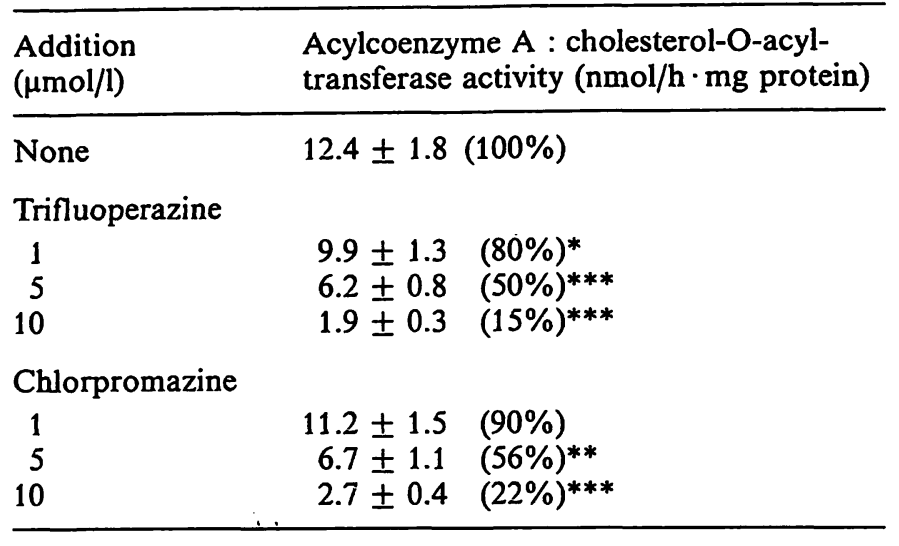

*: $\mathrm{p}<0.05 ;{ }^{* *}: \mathrm{p}<0.01 ; * * *: \mathrm{p}<0.001$ by the Student's t-test.

Tab. 5. Effect of trifluoperazine and chlorpromazine on $\left[{ }^{3} \mathrm{H}\right]$ cholesteryl ester metabolism by $\mathrm{J} 774$ monocytelike cells. Cells were preincubated for $24 \mathrm{~h}$ with or without drugs $10 \mu \mathrm{mol} / 1$ in Dulbecco's MEM medium before addition of $10 \mathrm{mg} / \mathrm{l}$ of $\left[{ }^{3} \mathrm{H}\right]$ cholesteryl linoleateloaded acetylated LDL. After a further $24 \mathrm{~h}$ incubation, cells were extensively washed, harvested and lipid analysis performed as described in materials and methods. Results are expressed in $\mathrm{fmol} / \mathrm{mg}$ of cellular protein (means of 4 experimental values \pm S. C.).

\begin{tabular}{lllll}
\hline $\begin{array}{l}\text { Effector } \\
(\mu \mathrm{mol} / \mathrm{l})\end{array}$ & \multicolumn{2}{l}{ Radioactivity recovered in } & Total \\
\cline { 2 - 4 } & $\begin{array}{l}\text { free } \\
\text { cholesterol }\end{array}$ & $\begin{array}{l}\text { cholesteryl } \\
\text { esters }\end{array}$ & \\
\hline $\begin{array}{l}\text { None } \\
\text { Trifluoperazine }\end{array}$ & $460 \pm 65$ & $265+ \pm 38$ & $725(100 \%)$ \\
10 & $310 \pm 52^{*}$ & $33 \pm 8^{* * *}$ & 343 & $(47 \%)$ \\
$\begin{array}{l}\text { Chlorpromazine } \\
10\end{array}$ & $370 \pm 70$ & $48 \pm 13^{* * *}$ & 418 & $(58 \%)$ \\
\hline
\end{tabular}

$*: \mathrm{p}<0.05 ; * * *$ p $<0.001$ by the Student's t-test.

tions of drugs must be utilized to observe a significant effect: about $50 \%$ decrease was observed both for chlorpromazine or trifluoperazine $(100 \mu \mathrm{mol} / \mathrm{l})$, and about $80 \%$ decrease was noted at $500 \mu \mathrm{mol} / \mathrm{l}$.

It was also of interest to investigate the effects of phenothiazines on the metabolism of exogenous cholsteryl esters introduced into cells by means of the scavenger receptor pathway. We thus loaded acetylated LDL with cholesteryl linoleate labelled in the cholesterol moiety and measured the radioactivity recovered in free and esterified cellular cholesterol after a $24 \mathrm{~h}$ incubation of $\mathrm{J} 774$ cells with radioactive acetylated LDL. The results are shown in table 5. Trifluoperazine or chlorpromazine $(10 \mu \mathrm{mol} / \mathrm{l})$ strongly decreased the radioactivity recovered in cholesteryl esters after a $24 \mathrm{~h}$ incubation with cholesteryl linoleate-labeled acetylated-LDL. It can be seen that the radioactivity recovered in free cholesterol was less affected, with about $20-30 \%$ decrease compared with the control. The total radioactivity recovered in cholesterol (free + esterified) was decreased about $50 \%$ and $40 \%$ in the presence of trifluoperazine or chlorpromazine $(10 \mu \mathrm{mol} / 1)$, respectively.

\section{Discussion}

This work demonstrates that phenothiazines strongly inhibit oleic acid incorporation into cholesteryl esters and acyl coenzyme A : cholesterol-O-acyltransferase activity in J 774 monocyte-like cells. This effect appears to involve at least two mechanisms: a reduction of acetylated LDL degradation (tab. 3), and a direct inhibition of the enzyme acyl coenzyme $A$ : cholesterol-O-acyltransferase (tab. 4). In previous studies, Bell reported that chlorpromazine inhibited cholesterol esterification in arterial tissue and isolated arterial microsomes (8). Acylcoenzyme A : cholesterol$\mathrm{O}$-acyltransferase activity of isolated arterial microsomes was diminished in vitro by about $50 \%$ in the presence of $100 \mu \mathrm{mol} / \mathrm{l}$ chlorpromazine and by more than $95 \%$ at $1 \mathrm{mmol} / \mathrm{l}(8)$. These values are close to that found in our experiments. More recently, Stein \& Stein (17) demonstrated that verapamil, another calcium antagonist drug, inhibited cholesterol esterification in the J 774 cell line. However, these authors did not find a direct effect of this drug on the acylcoenzyme A : cholesterol-O-acyltransferase activity, and concluded that this inhibition could be related to an impaired lysosomal hydrolysis of exogenous cholesteryl ester and a subsequent decrease in the delivery of free cholesterol to the site of acylcoenzyme A : cholesterol-O-acyltransferase regulation.

The inhibitory effect of phenothiazines on the degradation of acetylated LDL by $\mathrm{J} 774$ cells is probably related to the antagonistic effect of these drugs on calmodulin-dependent mechanisms. In previous studies, Van Berkel et al. demonstrated a reduction of acetylated LDL catabolism by trifluoperazine in another experimental system, the rat liver non-parenchymal cell (18). In fibroblasts, we also found a strong inhibition of native LDL degradation by calmodulin antagonists such as trifluoperazine or calmidazolium (5). These effects are probably dưe to an interaction 
of the drugs with some cytoskeleton components involved in the endocytic processes, leading to a decrease in acetylated LDL delivery to lysosomes.

The mechanism by which phenothiazines directly inhibit the acylcoenzyme A : cholesterol-O-acyltransferase activity is probably related to alterations in the membrane ultrastructure, and especially in the physical state of membrane lipids: various amphiphilic compounds exhibiting local anaesthetic properties are able to inhibit acylcoenzyme A : cholesterol-O-acyltransferase activity (19). Interaction of amphiphilic compounds with membrane phospholipids, with a subsequent increase in membrane fluidity, has been reported in several experimental systems $(20,21)$. As acylcoenzyme A : cholesterol-O-acyltransferase appears to be very sensitive to alterations of its microsomal membrane microenvironment (22), it is likely that the inhibition of this enzyme activity could be related to the interaction of phenothiazines with cellular membranes.

The dramatic reduction by chlorpromazine and trifluoperazine of the re-esterification of cholesterol entering via the acetylated LDL pathway is of particular interest. This results in a strong reduction of the radioactivity recovered in the cholesteryl ester fraction, and also in a decrease of the total cell-bound radioactivity (free + esterified cholesterol). This might be due to a stimulation of cholesterol efflux from the monocyte-macrophage cell, since the slow calcium channel blocker, nifedipine, has been reported to promote cholesterol efflux from mouse peritoneal macrophages (23).

The inhibitory effect of phenothiazines on cholesterol esterification has not yet been reported in the mono- cyte-macrophages. This phenomenon may be of great interest in view of the fact that cholesteryl ester accumulation is currently believed to be one of the main features involved in the formation of atherosclerotic lesions (1). Massive cholesteryl ester accumulation in monocyte-derived macrophages is due to the nondown-regulated uptake of LDL, probably modified by oxidative processes (24). These modifications are the result of a decreased turnover of the LDL in subjects presenting a defect in the apolipoprotein B/Especific receptor pathway, which results in an increased half-life of the LDL in plasma. It would therefore be of interest to reduce cholesteryl ester accumulation in monocyte-macrophages: this may be an alternative way of preventing atherogenesis. At present, the therapeutics of atherogenesis in heterozygous subjects with familial hypercholesterolaemia are mainly based on the induction of the apolipoprotein $\mathrm{B} / \mathrm{E}$ receptor by inhibitors of cholesterol synthesis such as mevinolin (25), and inhibitors of intestinal bile acid reabsorption such as cholestyramine (26). But it must be emphasized that such therapeutics only result in a moderate increase in LDL catabolism by the specific receptor pathway, and that they do not act on the process directly involved in atherogenesis, e. g. cholesteryl ester accumulation by macrophages. Moreover, inhibitors of cholesterol synthesis evidently fail to accelerate LDL turnover in homozygous subjects with familial hypercholesterolaemia. In this case, the only steps which can be influenced by therapeutic agents are cholesterol synthesis and cholesteryl ester accumulation by macrophages. The use of amphiphilic cationic drugs especially designed for this purpose may therefore have interesting therapeutic possibilities.

\section{References}

1. Gerrity, R. G. (1981) Am. J. Pathol. 103, 181-190.

2. Mahley, R. W., Innerarity, T. L., Weisgraber, K. H. \& Ho, Y. K. (1979) J. Clin. Invest. 64, 743-750.

3. Goldstein, J. L., Ho, J. Y., Basu, S. K. \& Brown, M. S. (1979) Proc. Natl. Acad. Sci. USA 76, 333-337.

4. Fogelman, A. M., Haberland, M. E., Seager, J., Hokom, M. \& Edwards, P. A. (1981) J. Lipid Res. 22, 1131-1141.

5. Mazière, J. C., Mazière, C., Gardette, J., Routier, J. D., Wolf, C., Rainteau, D. \& Polonovski, J. (1983) FEBS Lett. 162, 396-399.

6. Polonovski, J., Mazière, J. C., Mazière, C., Mora, L., Gallié, F., Gardette, J., Barbu, V. \& Roux, C. (1986) In: Lipid Metabolism and its Pathology (Halpern, M. J., ed.) II, pp. 19-27, Elsevier.

7. Bell, F. P. (1981) Atherosclerosis 39, 517-525.

8. Bell, F. P. (1983) Exp. Mol. Pathol. 38, 336-345.

9. Havel, R. J., Eder, H. A. \& Bragdon, J. H. (1955) J. Clin. Invest. 34, 1345-1353.
10. Basu, S. K., Goldstein, J. L., Anderson, R. G. W. \& Brown, M. S. (1978) Proc. Natl. Acad. Sci. USA 73, 3178-3182.

11. Bilheimer, D. W., Eisenberg, S. \& Levy, R. I. (1972) Biochim. Biophys. Acta 260, 212-221.

12. Lowry, O. M., Rosebrough, N. J., Farr, A. L. \& Randall, R. J. (1951) J. Biol. Chem. 193, 265-275.

13. Brown, M. S., Dana, S. E. \& Goldstein, J. L. (1975), J. Biol. Chem. 250, 4025-4027.

14. Friedman, G., Stein, O., Halperin, G., Kimchi, A. \& Stein, Y. (1978) Atherosclerosis 30, 185-198.

15. Mazière, J. C., Mazière, C., Mora, L. \& Polonovski, J. (1987) J. Biochem. Biophys. Meth. 14, 267-272.

16. Mazière, C., Mazière, J. C., Mora, L., Auclair, M. \& Polonovski, J. (1986) Lipids 21, 525-528.

17. Stein, O. \& Stein, Y. (1987) Arteriosclerosis 7, 578- 584.

18. Van Berkel, T. J. C., Nagelkerke, J. F., Haarkes, L. \& Kruijt, J. K. (1982) Biochem. J. 208, 493-503. 
19. Morin, R. J., Edralin, G. G. \& Woo, J. M. (1974) Atherosclerosis $20,27-39$.

20. Chatelain, P., Reckinger, N. \& Roncucci, R. (1979) Biochem. Pharmacol. 28, 3677-3680.

21. Ogiso, T., Masahiro, I. \& Mori, K. (1981) Biochim. Biophys. Acta 649, 325-335.

22. Mitropoulos, K. A., Knight, B. L. \& Reeves, B. E. A. (1980) Biochem. J. 185, 435-441.

23. Schmitz, G., Robenek, H., Beuck, M., Krause, R., Schurek, A. \& Niemann, R. (1988) Arteriosclerosis 8, 46-56.
24. Fogelman, A. M., Shechter, I., Seager, J., Hokom, M., Child, J. S. \& Edwards, P. A. (1980) Proc. Natl. Acad. Sci. USA 77, 2214-2218.

25. Bilheimer, D. W., Grundy, S. M., Brown, M. S. \& Goldstein, J. L. (1983) Proc. Natl. Acad. Sci. USA 80, 41244128.

26. Shepherd, J., Packard, C. J., Bicker, J.', Lawrie, T. D. V. \& Morgan, H. G. (1980) New Engl. J. Med. 302, 1219-1222.

Dr. J. C. Mazière

Laboratoire de Biochimie Faculté de Médecine

Saint-Antoine

27 rue Chaligny

F-75012 Paris 